\title{
Analysis of Human Needs under Basic Principles of Marxism
}

\author{
Zhao-xia Qu \\ Second District of North China Electric Power \\ University(China) \\ Hebei province Baoding City
}

\author{
Jing-Song * \\ Second District of North China Electric Power \\ University(China) \\ Hebei province Baoding City
}

\begin{abstract}
Marx said that "human nature is the sum of all social relations in its reality. "Man is a product of social activities; he has physical and spiritual needs, both dialectical unity. The realization of human freedom is the highest value of the pursuit of comprehensive development of Marxism. Under the reform, opening up and socialist modernization continuous development strides background. The relationship between economic interests of the people is changing, their spiritual needs also changing, and the emergence of many new features. Adhering to the people-centered scientific concept of development, and meeting the spiritual needs of people for the realization of self-improvement, maintaining social stability is of great practical significance.
\end{abstract}

\section{Keywords-Essence of man; Spiritual needs; People-oriented}

\section{INTRODUCTION}

Our country has always attached importance to the power of "people" , the ancient Confucianism respected "benevolent", "Do unto others, do not impose on others", promotes the rule of virtue, request rulers should have the heart of love. Mo raised the "Fraternity", the idea that love your neighbor as yourself, regardless of you and me, and the pursuit of equality between people; in modern times, after "Five - Four" campaign, the feudal yoke was broken, people's thoughts and personality were fully liberated of humanity ,there has also been lifted, embarked on the road of individual liberation, this stage has become one of the most thought Praise period. In western societies, as early as Roman times the initiation of the people of this ideology, to the liberation of the Renaissance raised people's thoughts, to encourage people to pursue earthly happiness. The industrial Revolution and the bourgeois revolution, with Rousseau as the representative of Western humanism scientists advocating the pursuit of "equality, liberty, fraternity" and other ideas. It is not difficult to find, in western society, people who study people's spiritual demand has played an important role.

In the reform and opening up and socialist modernization continue to make great strides in the development background, the third plenary session of the sixteenth on the "decision" put forward the concept of scientific development. In the congress report also stressed that the core of the scientific concept of development is people-oriented, the "people" demand as the starting and ending points. This is not only the Chinese Communists insist on serving the people wholeheartedly embodies the fundamental purpose of the party, but also of Marxism in China was the latest achievement, and Marx philosophy of human theory is closely connected with.

\section{ANALYSIS OF HUMAN NEEDS}

Related to the people's problems, we have to talk about the Essence of man, Marx's ideas about human nature there are three main propositions .First, the "labor or practice is Essence of man", that practice is the most essential difference between humans and animals. Second, in Marx's "Theses on Feuerbach "points that: "Human nature is not a single individual abstraction inherent in its reality, it is the sum of all social relations. Society is the essential attribute of man. Third, "The human nature is the human need." Marx in "The German Ideology" pointed out: "They need that is their nature." The history of human development, is an ever-changing needs of people and the history of the development. If you leave the people's needs, all the people and all social relations practice will cease to exist. Individual needs is the premise of human practices and social relations. In addition, the "man" is the fundamental driving force of social development. Marxism view the free and full development of the human as the highest value targets, the first of all from the height of the fundamental theory to explain why we should pay attention to the needs of people.

In humans into the twenty-first century, humans has reached unprecedented material wealth, greatly satisfied people's growing material needs, and also greatly satisfied the needs of the human spirit. After twenty years of China's reform and opening up , the development of material civilization is very fast. People's living standards greatly improved, can have much more substance than in the past. So, the spiritual needs of people are more intense. However, there are some people blindly pursue substance that he is simply a money machine in today's society, ignoring the spiritual quest, leading to even wealthy, spiritually poor, extremely empty. Undoubtedly, such a person is a freak. Mr. Lu said, whatever stupid weak nationals, even though how robust physique, how to thrive, they can only make meaningless public display materials and spectators, it is 
not necessary to think that the number's dead is unfortunate. In today's perspective, these words still has its practical significance. In the new era, due to accelerated pace of life and intense competition, it may lead to the alienation of the human spirit. Many people unable to extricate themselves in the face of the surging tide of lost material.

However, people have spiritual needs of man is one of the signs of people. This can be one standard that why person is different from the animals in a way. As we all know, animal almost do not want nothing except substances. But man is different, who in addition to the material, but also the pursuit of the spirit, and the people's spiritual needs is essential. Under the guidance of the people-oriented concept of society, people's spiritual needs should be fully respected and fulfilled.

\section{PEOPLE'S SPIRITUAL DEMAND RELATIONS WITH MATERIAL NEEDS}

According to the difference of objects, human needs can be divided into Material needs and spiritual needs. In different social development period, the demand of people is different . In the stage of pre-capitalism which had low productivity, because the production tools and production technology limited, Hunger, cold and other basic necessities of life was the most important problem that people needed to solve, so the need of improving the level of material life is the first. This is agree with the basic national conditions of China, which is that we should put the vigorous development the productive forces in the first place without prior without previous consultation. In modern times, with the development of the industrial revolution and the revolution of science and technology, especially in the western capitalist society, material wealth has been greatly enriched, and people's spiritual needs are put in an important position. The people shouted "knowledge is power", Audit is not difficult to find many great books appear this time. Material needs and spiritual needs are not separate, but dialectical unity. Material needs and spiritual needs are a pair of contradictions, the two are different from each other, each of which has a relative independence, but the two are interdependent and are premise conditions of existing, it is also in this interdependence in material and spiritual demand that they won their own different rules.

Compared with the material needs, spiritual needs show more complexity. People's spiritual need is a multi-level, in different social backgrounds and different historical conditions, people's spiritual needs are different. And specifically, because of different individual endowments and different occupation and age differences, people show different spiritual needs. For example, high school students pay attention to adolescent personality, they both eager to maintain individuality and hope to be admitted; a soldier more emphasizes the sense of honor and sense of responsibility; university graduates just entering the society need to find their own value in the confusion. Compared with the material needs, spiritual needs expressed as an infinite, unlimited, multi-level and complex demand.

\section{THE MARXIST VIEW OF MAN'S SPIRITUAL NEEDS INSPIRATION FOR MODERN SOCIETY}

With the deepening of reform and opening up, people's material living standards have been phased increase, People do not only pay attention as to feed and clothe. such as many restaurants have put spiritual things as a feature to attract customer. For example, some restaurants introduced by the customer on the phone in temporary custody before a meal together at the same time in order to give the customer a discount in return, which is no longer satisfied with simply eat a good meal, the restaurants pay more attention to advocate people to communicate feelings. this practice was well received, which showed that people from the side of the spiritual quest has been involved in all aspects of life. People are pursuing interests and speed . people's material needs have been met, and more and more people pay attention to people's spiritual needs. People's material needs are the basis of spiritual needs, while the spiritual needs are in higher level compared with material needs.The Promote of market economy, should not be at the expense the improvement of people's living standards should not lead to the poor in spirit. Peopleoriented is based on the "human" needs,which is aim at meeting people's need and servicing more people, so as to realize the harmonious development of society as a whole.

In today's knowledge explosion, people all the time to receive a lot of information and knowledge. Face book founder Mark Zuckerberg has said that it would be equivalent to the amount of information to share the current 1000 times in the next decade. People's ideology and concepts are increasingly varied, people in the pluralistic culture, constantly enrich the spiritual needs increase, which is people-oriented made more realistic and specific requirements. In the mainstream ideas of socialist core values, respecting and meeting the spiritual needs of individuals, developing variety of cultural programs and guiding the correct concept of health is the construction of contemporary China, so to achieve a harmonious society should the question of meaning.

\section{REFERENCES}

[1] The complete works of Marx Engels. Volume 42[M]. Beijing: People's Publishing House, 1979.

[2] Marx. Economic and Philosophical Manuscripts of 1844[M]. Beijing: People's Publishing House,2000.

[3] The complete works of Marx Engels. Volume 23. Beijing: People's Publishing House, 1972.

[4] The complete works of Marx Engels. Volume 32. Beijing: People's Publishing House, 1974.

[5] Tu Chunyou.the Socialist Harmonious Society [J]. Theory guide, 2004,12.

[6] Lin Mengwan. Philosophical reflection on building a harmonious society society [J]. Marxism Studies, 2005,4

[7] Shi Chuanxi. Content of "the Human Development" theory [J]. Forefront, 2006, 7 